Retire in 1911 : Mr. 1H. 'T. Butlin, St. Bartholomew's Hospital (first elected 1895); Mr. G. H. Makins, St. 'Thomas's 'Hospital ; and Mr. O. 'T. Dent, St. George's Hospital.

Retire in 1910: Professor ILoward Marsh, St. Bartholomew's Hospital (first clectel 1892); Mr. J. H. Moryan, Charing Cross Hospital ; and Mr. H. II. Clutton, St. 'Jhomas's Hospital.

Retire in 1309 : Mr. A. W. Mayo Robson, Leeds Infirmary (first elected 1893) ; Mr. W. Watson Cheyne, King's College Hospital ; and Mr. R. Clement Lucas, Guy's Hospital.

Retire in 1908: Dr. J. Ward Cousins, Royal Portsmouth Hospital (first elected 1895); and Mr. A. Pearce Gould, Middlesex Ho-pital.

Retire in 190' : Mr. H. W. Page, St. Mary's Hospital; and Mr. C. W. Mansell Moullin, London Hospital.

Retire in 1906: Mr. J. Tweedy, President, University College Hospital (first elected 1892); Mr. F. Richardson Cross, Bristol Royal Infirmary ; Mr. Henry Morris, Middlesex Hospital (first elected 1893); and Mr. John Langton, St. Bartholomew's Hospital (first elected 1890).

Retire in 1905 : Sir Henry G. Howse, Guy's Hospital (first elected 1889) ; Mr. Edmund Owen, St Mary's Hospital ; and Mr. Rickman J. Godlee, University College Hospital.

Monday, June 12th, was the last day for receiving nominations and we understand that there are only six candidates for the four vacant seats. They are : $\mathrm{Mr}$. Owen and $\mathrm{Mr}$. Godlee, who are applying for reappointment; $\mathrm{Mr}$. C. H. Golding-Bird, Mr. Andrew Clark, Mr. W. Bruce Clarke, and Mr. W. Harrison Cripps. It is a long time since there have been so few candidates for four vacant places. There can be only two unsuccessful candidates.

The Fellows' dinner held in 1904 was very successful and it has therefore been decided to hold a Fellows' dinner again this year. As the space available is limited it may be necessary to ballot for places but all applications for tickets should be made before June 22 nd.

\section{HOSPITAL SERMON.}

\author{
By Rev. C. H. GRUNdy, M.A., \\ VICAR OF ST. PETER'S, BROCKLEY.
}

"Gifts of healing"-I. Cor. xii. 9.

OxCE a year all party strife ceases in the religious world of London. No word of bitterness issues from the pulpits of London to-day. The question is not "What body of Christians do I belong to?" but "What can each one do to relieve the mass of suffering humanity in this great metropolis, larger in its population than Babylon, Thebes, .or Rome ever was?" Hushed is the voice of controversy in the presence of disease and pain. The "deep sighing of the poor" in their anguish reaches all our ears, as from thousands of pulpits the call goes out to help men, women, and children in their need, struck down by accident or visited by disease. Their extremity is the measure of our sympathy and their weakness the strength of their claim upon us. There are countless opportunities for pain in the human body, so that the wonder is that health is sustained at all. Huxley says: "The human body is an army. Each cell is a soldier. An organ is a brigade. The central nervous system is the headquarters and field telegraph. The alimentary canal and circulatory system are the commissariat. Each cell has its life, duties, waste, repair, growth, and decay."

What complex beings we are! The phrase "being ill"who does not know what that means, in himself, in loved ones, in the tender work of nursing, in the hours of agony when the doctor whispers "Nothing more can be done"? People in rude health joke sometimes about "not believing in doctors," but what a panic there is in the house the moment someone is smitten down by illness. The sudden stroke, the epidemic, the collapse from overwork, the wasting disease, the young wife hovering between life and death that another soul may enter upon earth, the little child at school one week and at death's door the next, the stranger calling to break the sad news at home that the husband has met with an accident in the street and is now in hospital; how familiar all these are to us, yet what anxiety, sorrow, and dread they represent. A serious illness taxes to the utmost all the capacities of even a well-to.do household.
Things to be bouglit, thought of, borrowed, attempted; the nights of watching, the days of consultation, the visit of the specialist, the tension of the climax, the joy of hope, and the weary convalescence-what an experi. ence for the members of the comfortable home. What gratitude afterwards to the patient doctor whose skill has saved your darling! But where did he learn it all? What training made him calm and resourceful and ready with the best and latest treatment in that hour of misery when all else seemed to fail? You owe the life of your loved one to the hospital. It was there that the rescuer of your dear one was taught what to do, and when to do it, and how to do it. You owe ransom money to the hospitals, for without them there would have been the empty chair beside your hearth. Year by year they supply men able, qualified, experts in their work, levoted to their duty, responsive to the call of suffering, and quick to diagnose and to act.

There is no band of men more unselfish, more untiring, more thoughtful, more capable than the brotherhood of the medical profession in London. Often-very often-no fee is received by them after weeks of tender, assiduous attention to some critical case. These are the saviours of humanity and their success is due to the schools of the hospitals for which I plead to-day. Among the noble army of medicine and surgery some names are remembered. They have struck the popular imagination. What recollections are recalled by names like Paget, Lister, Horrocks, Jenner, Gull, Treves, and many others which could be mentioned. If the Church has its saints the hospitals have noble benefactors of mankind. If the Church points out salvation for the souls of men let us not forget what the hospitals have done for their bodies. Christ was the healer of the body as well as the soul and the hospitals in His name undertake the care of their bodies. The hospital is the sick room and the invalids' shelter amongst the poor. It would do you good to go to a children's hospital, say, the one in Great Ormond-street, and see a patient, sweet, clean child in its dainty cot, suffering from, say, hip disease, and then go and see the dirty squalid home from which the child came.

What would Whitechapel do without the 840 beds of that splendidly managed hospital - the London Hospital-willing to receive the crowds of sick from one-roomed homes? How many lives have been saved at Guy's of railway men half killed on the shuntings of two great railway companies? What an awful thing for Westminster or the locality round St. Thomas's if there were no hospitals! You would double your subscription if you realised the boon to the masses of this great metropolis. The scientific gifts of healing are the glory of England and the intstimable blessing of the poor. London with its wealth should not be content with a paltry $£ 60,000$ as its response to the annual appeal. $£ 100,000$ would be an easy and a willing gift on a day like this did men and women realise their duty to the poor and the Christ-like work done by the hospitals in this city of suffering.

\section{Looking JBack.}

\section{THE LANCET, SATURDAY, June 16, 1827.}

As the opinion which we form of the nature of a disease must be true or untrue, and as the treatment is founded upon that opinion, hence arises the absolute necessity of possessing correct principles of pathology, that dogmatism may be avoided on the one hand and empiricism on the other; or rather, that we may avoid a series of hazardous experiments on the health and lives of confiding patients, ignorant of the imperfections of the professors of an art, which has been too long concealed under a language almost as incomprehensible, to common minds, as the hieroglyphics of the ancient Egyptians; yet all that is really known, in modern medicine, might be expressed in a few plain English words, the rest being merely verbiage, a part of the mummery and mystery of scholastic and collegiate sophistry. Indeed, no part of human knowledge has been till recently kept so completely concealed from the public view as medi. cine, and this is the reason why some of its professors have risen to the highest distinctions without substantial attain. ments. The public can judge of the abilities of a barrister but their ignorance of the elements of physic utterly prevents 